\title{
Social Transformations in the Women's Short Stories in Egypt, 2011-2017
}

\author{
Mohammed Almahfali \\ Center for Middle Eastern Studies \\ Social Science Faculty, Lund University, Lund. Sweden \\ Rafah Barhoum \\ Center for Middle Eastern Studies \\ Social Science Faculty, Lund University, Lund. Sweden
}

\begin{abstract}
This study primarily draws on genetic structuralism in unraveling social transformations embedded in short stories written by Egyptian authoresses. It also makes use of feminist concepts given that the content in question is written by Egyptian women writers and hence blends general social transformations with those affected by feminism. Four Egyptian authoresses were selected for this study along with samples of their literary works, written between 2011 and 2017, in an attempt to unpick the social transformations taking place in the short story during that critical period. The study shows that social transformations begin with the subject that is aware of those transformations embedded in the short story and taking different forms. It, in addition, underlines the impact and significance of the setting and how it is used by the women writers to locate and shed light on those transformations. Moreover, there are two types of social transformations, namely negative transformation, embodied in the deterioration of social relations or any undesired behavior, and positive transformation, characterized by the awareness of the subject of the sources of power in relation to the act of change and the influence of the revolutionary action on it. In addition, feminist conceptions are shown to be used in resisting male dominance and its relation to social oppression.
\end{abstract}

Keywords: Egypt, genetic structuralism, social transformations, sociology of literary, women's short stories

Cite as: Almahfali, M., \& Barhoum, R. (2018). Social Transformations in the Women's Short Stories in Egypt, 2011-2017. Arab World English Journal for Translation \& Literary Studies, 2 (1). DOI: http://dx.doi.org/10.24093/awejtls/vol2no1.4 